\title{
Fiscal Externalities in Local Tax Competition: Empirical Evidence from a Panel of German Jurisdictions
}

\author{
Thiess Buettner ${ }^{1}$
}

February, 2001

Institutional affiliation:

Centre for European Economic Research (ZEW), Mannheim

Martin School of Public Policy and Administration, University of Kentucky

\section{Address:}

Martin School of Public Policy and Administration

University of Kentucky

415 Patterson Office Tower

Lexington Kentucky, 40506-0027

e-mail: buettner@zew.de

\section{Abstract:}

This paper is concerned with fiscal externalities arising from local taxation of a mobile factor. Using a panel of more 1100 local jurisdictions it provides empirical evidence on how the local tax rate as well as the tax rate in the neighborhood affect the local tax base. The results support the existence of fiscal externalities: an increase in the tax rate of local neighbors exerts a positive effect on the tax base whereas an increase of the own tax rate has a negative effect, and a joint increase of the tax rate at the local jurisdiction and in its neighborhood has no significant effect on the interjurisdictional distribution of the tax base. However, in the considered case tax competition is alleviated by revenue sharing rules which reduce the jurisdictions' incentive to lower tax rates in order to attract capital.

Keywords: Local Capital Taxation, Fiscal Externalities, Tax Competition, Fiscal Equalization Grant, Empirical Investigation, Panel Data, Generalized Method of Moments

JEL-Codes: H71,H72,H73,C23,D62

\footnotetext{
${ }^{1}$ I would like to thank Harry Huizinga, Bob Inman, and seminar participants at the ZEW Summer School, 2000, Mannheim, the CESifo Summer Institute, 2000, Venice, the Annual Meeting of the VfS, 2000, Berlin, the OCFEB Workshop on Tax Competition in the EU, 2000, Den Haag, and at Dortmund University for helpful comments. I am grateful also to Jonathan Beck who helped me to prepare the database.
} 


\section{Introduction}

The literature on tax competition has emphasized that taxation of a mobile factor may, under certain circumstances, lead to a situation where taxing decisions have an impact not only on the own budget but on that of other jurisdictions as well (cf. Wilson, 1999, for an overview). It has been shown that these fiscal externalities are the essential distortion behind an inefficiency of tax competition since they increase the marginal cost of decentrally raising public funds (cf. Wildasin, 1989). But, whereas the theoretical literature has already explored the conditions under which fiscal externalities arise, empirical evidence on the magnitude of the distortions is still lacking (e.g., Oates, 1999). Differences in taxation of mobile factors are probably most striking at the international level but their empirical analysis is facing major obstacles. Given the complexity of national tax systems it is difficult to work out the precise fiscal incentives provided by these systems. Moreover, the reporting of cross-border activities is often quite unsatisfactory. Therefore, it seems important to augment the existing empirical evidence by studying the effects of local taxation in federal countries. They often combine the existence of highly open jurisdictions engaged in tax competition with comparable institutions, tax codes, and data.

Several studies have already established significant correlations between the taxing decisions of neighboring local jurisdictions (e.g., Ladd, 1992, Brett / Pinske, 1997, 2000, Brueckner / Saavedra, 2000, Buettner, 2001). In these studies, the geographic proximity of jurisdictions is taken as an indicator of their exposure to interjurisdictional competition. However, correlations of taxing decisions might simply arise from mimicking neighbors's policies in a yardstick competition (Besley / Case, 1995) without any effects on the tax base. Therefore, these studies provide empirical evidence for the existence of tax competition at the local level, but do not necessarily imply the presence of distortions.

This paper takes a different route and focuses directly on the tax base effects of local tax rates in a context of capital taxation. It employs a large panel of local jurisdictions in a major German state which set the local tax rate of the business tax. By testing whether both the local tax rate as well as the tax rate of neighboring jurisdictions have a significant impact on the tax base, this approach explicitly delivers evidence on the existence of fiscal externalities. Estimation is carried out with a flexible generalized method of moment (GMM) approach to dynamic panel data analysis suggested by 
Holtz-Eakin et al. (1988).

The results confirm the existence of horizontal fiscal externalities from local taxation, as the tax rate of neighboring jurisdictions shows a significant positive effect on the local tax base whereas the own tax rate shows as a significant negative effect. In absolute value the two effects are about the same size indicating that a joint increase of the tax rate at the local jurisdiction and in its neighborhood has no effect on the interjurisdictional distribution of the tax base. The rather large estimate for the effect of the own tax rate on the tax base is shown to be consistent with a policy of local jurisdictions, which is maximizing revenues net of fiscal transfers. The emphasis on net revenues is important, since in the considered case substantial transfers are related to the tax base due to revenue sharing and, thereby, reduce the adverse tax base effects of tax increases for the individual jurisdiction.

The next section derives the impact of the local tax rate on the tax base in a stylized theoretical model with interregional factor mobility and factor taxation. It yields a testable relationship between the local tax base, the tax rates both of a local and a competing jurisdiction, and the grants received by the jurisdictions. The empirical section investigates this relationship using a panel of local jurisdictions. It starts with a description of the data and specification issues. After presenting the results, the implications for the local tax policy and the role of the revenue sharing system are discussed, followed by the conclusions.

\section{Theoretical view: fiscal impacts on the tax base}

In order to derive a relationship between the local tax base and local tax rates this section presents a simple model of tax competition where two jurisdictions are restricted on their revenue side to use a tax on the mobile factor. The analysis is kept simple by assuming that the local economy uses only two factors: capital and labor. Capital is assumed to be mobile without cost across jurisdictions, whereas the local supply of labor is assumed to be fixed. The local economy produces a single good according to the production function,

$$
y_{i}=g\left(e_{i}\right) f\left(k_{i}\right), \quad g^{\prime} \geq 0
$$


where $y_{i}$ denotes output per worker and $k_{i}$ denotes the capital intensity at location $i$. $f$ is a linear homogenous production function in intensity form and $g$ is a neutral shift term capturing the non-negative productivity impact of an all-purpose public good $e_{i}$, also expressed in units per worker. Accordingly, public goods serve as a factor augmenting input (cf. Matsumoto, 1998). Taking account of possible productivity effects of local public expenditures allows us to capture the role of public infrastructure for business location. The revenue side of the local government's budget constraint consists of tax revenues and grants

$$
e_{i}=\tau_{i} b_{i}+z_{i}
$$

where $z_{i}$ denotes grants per worker, $b_{i}$ denotes the tax base per worker, and $\tau_{i}$ is the tax rate. Assuming a static setting the budget is always balanced and no deficit or surplus can be run by the local government. The tax is levied on local capital income, formally

$$
b_{i}=g\left(e_{i}\right) f^{\prime}\left(k_{i}\right) k_{i} .
$$

This specification of the local tax base deviates from the common set-up in the literature which employs a tax on capital rather than on capital income (cf., Wilson, 1999), but the latter is more close to the subject of the empirical analysis. However, the empirical predictions of the model would be quite similar with a tax on capital.

The mobility of capital introduces an additional constraint to the local economy as it requires that the after tax rate of return is not different at any opportunity location. If region $j$ belongs to the set of opportunity locations of region $i$ this can be stated by the condition

$$
\left(1-\tau_{i}\right) g\left(e_{i}\right) f^{\prime}\left(k_{i}\right) \stackrel{!}{=}\left(1-\tau_{j}\right) g\left(e_{j}\right) f^{\prime}\left(k_{j}\right),
$$

requiring that the net marginal revenue of capital is equalized across locations. This condition plays a central role in the literature on tax competition, as it links the allocation of capital captured by $k_{i}, k_{j}$ with the local fiscal policies described by the tax rates $\tau_{i}, \tau_{j}$ and the supply of public goods $e_{i}, e_{j}$. Fiscal decisions affect the capital allocation in the following way. Consider the special case where public goods have no impact on productivity, i.e. $g\left(e_{i}\right)=1$. Then the increase of the tax rate at location $i$ will reduce the after tax rate of return at $i$, ceteris paribus. In order to reinstall interregional equilibrium, equation (4) suggests that capital moves out of location $i$ until the marginal productivity of capital is high enough to compensate 
higher taxation. The partial impact of public goods can be illustrated best in the opposite case, where public expenditures are productive and totally financed out of grants and the tax rate is zero. Then an increase in the grants received will cause an increase in the public good supply, and thereby an increase in marginal revenue of capital, ceteris paribus. Condition (4) then requires an inflow of capital in region $i$ until the marginal productivity is reduced sufficiently in order to compensate higher overall productivity.

The fiscal decisions will generate fiscal externalities if the movement of capital out of or into location $i$ affect the capital supply at location $j$. This becomes most obvious if we consider a case of only two locations, where the total supply of capital is fixed. Then, $k_{j}$ is fully determined by $k_{i}$ according to the full employment condition

$$
k_{i} l_{i}+k_{j} l_{j}=k, \quad l_{i}+l_{j}=1,
$$

where $k$ is the fixed overall capital supply per worker and $l_{i}$ is the given number of workers located at $i$. In this setting an increase of the tax rate at location $i$ will cause an outflow of capital at location $i$ and, simultaneously, an inflow of capital at location $j$. Similarly, an increase in grants to location $i$ will induce capital movements from $j$ to $i$.

Formally, the impact of the fiscal parameters on the local stock of capital can be obtained by total (logarithmical) differentiation of equation (4), taking into account that the local economy at both locations is described by the system (2), (3), and (5). After some calculations the following expression is obtained

$$
\begin{aligned}
& {\left[\frac{\varphi_{i}-\gamma_{i}}{1-\gamma_{i}}+\frac{\varphi_{j}-\gamma_{j}}{1-\gamma_{j}} \frac{k_{i} l_{i}}{k_{j} l_{j}}\right] \mathrm{d} \log k_{i} }= \\
&- {\left[\frac{\tau_{i}}{1-\tau_{i}} \frac{\gamma_{i}}{1-\gamma_{i}}\right] \mathrm{d} \log \tau_{i}+\left(\frac{\gamma_{i}}{1-\gamma_{i}} \frac{z_{i}}{e_{i}-z_{i}}\right) \mathrm{d} \log z_{i} } \\
&+ {\left[\frac{\tau_{j}}{1-\tau_{j}}-\frac{\gamma_{j}}{1-\gamma_{j}}\right] \mathrm{d} \log \tau_{j}-\left(\frac{\gamma_{j}}{1-\gamma_{j}} \frac{z_{j}}{e_{j}-z_{j}}\right) \mathrm{d} \log z_{j}, } \\
& \text { where } \quad \varphi_{i} \equiv-\frac{f^{\prime \prime}\left(k_{i}\right) k_{i}}{f^{\prime}\left(k_{i}\right)}, \quad \gamma_{i} \equiv \frac{g^{\prime}\left(e_{i}\right) e_{i}}{g\left(e_{i}\right)}\left(\frac{e_{i}-z_{i}}{e_{i}}\right) .
\end{aligned}
$$

$\varphi_{i}$ represents the elasticity of the marginal productivity of capital, and is assumed to be greater than zero and less than unity

$$
1>\varphi_{i}>0 \text {. }
$$


$\gamma_{i}$ is the elasticity of total productivity with respect to public expenditures times the share of tax revenues in the local budget. Thus, it determines the relative increase in local productivity resulting from an additional dollar in tax revenues. It is assumed to be non-negative and, in order to make sure that the bracket on the left hand side of equation (6) is positive, it is required to be less than $\varphi_{i}$

$$
\varphi_{i}>\gamma_{i} \geq 0
$$

By this condition the increasing returns introduced by the productivity impact of public expenditures are always dominated by the decreasing returns from holding constant the immobile factor. This is a standard assumption in models with factor mobility and increasing returns as it ensures the determinateness of the locational equilibrium (see Henderson, 1985, and Richter, 1994).

On the right hand side of equation (6) the two terms in squared brackets associated with the relative change of the tax rates contain the tax rates. Therefore, a prediction on the effects requires a statement about how the tax rates are set. There are many reasonable alternatives to specify an objective function for the local jurisdictions. But, as the focus is on the effect of local fiscal decisions and not on their determinants a comprehensive discussion is beyond the scope of this paper. However, if the tax rate $\tau_{i}$ is set lower than $\gamma_{i}$, the benefit from an increase in productivity due to a higher supply of the productivity enhancing public good is larger than the costs to the capital owners, and a higher tax rate is even in the interest of the taxpayer. Therefore, it is reasonable to restrict the set of policy choices by the requirement that

$$
\tau_{i} \geq \gamma_{i}
$$

With this condition, the impact of the local tax rate on the level of capital will be negative or zero, whereas the impact of the tax rate of the other jurisdiction will be positive or zero.

The relative change of the local tax base can be derived by differentiation of the equation of the tax base (3) taking account of the budget constraint (2) which results in

$$
\mathrm{d} \log b_{i}=\left(\frac{1-\varphi_{i}}{1-\gamma_{i}}\right) \mathrm{d} \log k_{i}+\left(\frac{\gamma_{i}}{1-\gamma_{i}}\right) \mathrm{d} \log \tau_{i}+\left(\frac{\gamma_{i}}{1-\gamma_{i}} \frac{z_{i}}{e_{i}}\right) \mathrm{d} \log z_{i}(7)
$$

The expression indicates that the tax base is increasing with the stock of capital installed locally. If public expenditures exert an impact on produc- 
Table 1: Comparative static effects on the tax base

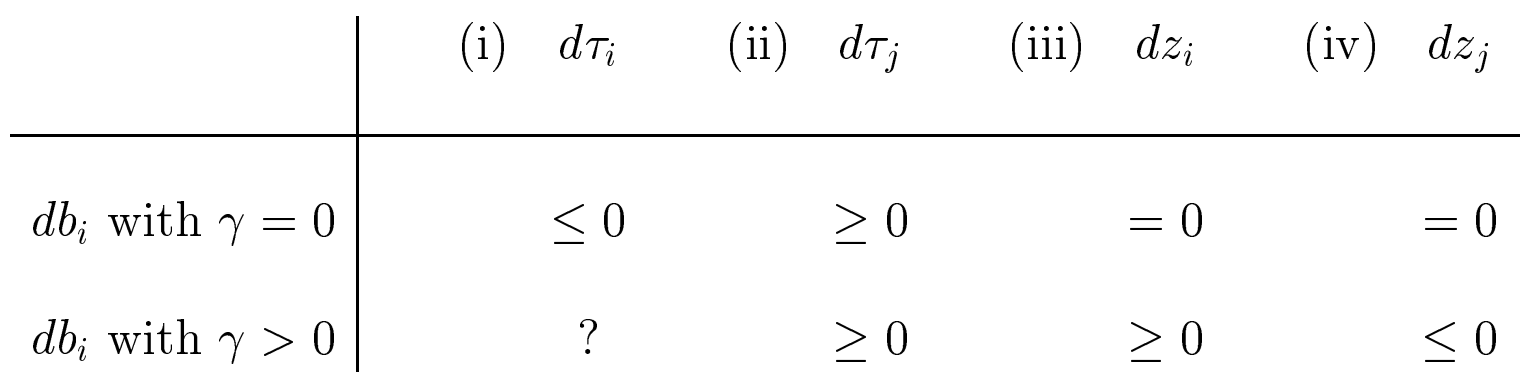

tivity there are also direct positive effects of the tax rate and of the level of grants received.

Expression (7) together with the equation for the change in the local stock of capital (6) allows us to derive predictions on the comparative static effects on the local tax base. According to equation (7) in the absence of productivity effects the tax base is driven only by the allocation of capital. Then, one should observe a non-positive impact of the own tax rate (i) and a non-negative impact of the other location's tax rate on the tax base (ii). From equation (6) it can be seen that in a symmetric case with similar tax rates and conditions in the two jurisdictions the size of the effects on the equilibrium capital stock should be similar in absolute value. Then, a joint increase in the tax rate would not affect the capital allocation and, hence, the distribution of the tax base. This is, of course, reflecting the assumption of the model that capital owners can only choose among jurisdictions and other supply effects are absent. In presence of a productivity impact of public goods, however, a prediction of the impact of the own tax rate is not possible without additional assumptions on the local policy objectives. For instance, if the local jurisdiction would maximize revenues the impact on the tax base would be negative, but if it were maximizing the supply of capital a positive effect may be found. However, it should be noted that regardless of the existence of productivity effects, if a negative impact on the own tax rate is empirically observed, the model offers an unambiguous explanation, namely that the equilibrium stock of capital is reduced. Similarly, a positive effect of the competing jurisdiction's tax rate indicates that the equilibrium capital stock is increased. If public goods do exert productivity effects, grants to the location $i$ will be positively related to the tax base, but grants to the other location will show a negative impact. The impact of grants to the other location is, however, not a standard fiscal externality, as it is not directly determined by decisions of the other location's 


\section{Empirical study of tax base effects}

The aim of the empirical investigation is to provide evidence on the comparative static effects of tax rates and grants on the tax base as derived above. It employs a panel of local municipalities or communities in a major German state. Whereas the German system of fiscal federalism mainly relies on a system of grants and tax revenue sharing and because it limits taxing discretion at the local level, the current study focuses on the business tax (Gewerbesteuer) which is the important exception to that system. ${ }^{2}$ The code is defined uniformly across Germany, but the local tax rate of the business tax is set by the communities. In case of firms with locations in different communities uniform rules define the allocation of the tax base to the individual communities according to the payroll. Therefore, the business tax might be a good empirical example of a local source based tax on the earnings of a mobile factor. Leaving a more detailed description of the institutional details to the appendix, the following section starts with a short description of the main characteristics of the dataset.

\subsection{Dataset}

The dataset consists of the complete set of communities in a major German state. It reports the revenues and tax rates from the business tax as well as the level of grants and population on an annual basis from 1980 until 1996 for more than 1100 jurisdictions. In the period under investigation the business tax precisely consisted of a combination of two taxes, one levied on business earnings the other levied on business capital. ${ }^{3}$ As the definition of taxable business earnings not only includes profits but also a major part of interest payments, the tax on business earnings can be regarded as a capital income tax. Unfortunately the local revenues derived from the two sources are not reported separately. Only at the national level information is available, indicating that the tax on capital income determines about 90 $\%$ of the revenues from the business tax. Given the inability to distinguish

\footnotetext{
${ }^{2} \mathrm{~A}$ short description of the business tax is provided in International Bureau of Fiscal Documentation (1994: 146).

${ }^{3}$ In 1997 the tax on business capital was abolished throughout Germany.
} 
empirically the two parts at the local level and given the dominance of the earnings, the business tax as a whole is approximated in the following by a tax on earnings (see appendix A for the details of the approximation).

The tax base is not actually observed but derived from the revenues after dividing them by the tax rate. Since the reported revenues consist of tax payments in advance net of tax rebates, the measured tax base is not strictly related to the current period and rather fluctuates around the true tax base (see appendix C). As is reported in Table 2 the tax base shows marked cross-sectional variation, ranging from more than 30,000 DM per capita to figures below zero. The negative figures indicate cases where the tax rebates exceed the payments in advance. But, note that this is only temporary, the long term average of the measured tax base is positive for all jurisdictions. In addition, the tax base shows a clear cyclical pattern, since the mean declines with the recession in the 1981/1982, shows highest levels during the unification boom in the early nineties, and declines afterwards in the slowdown.

The tax rate on capital income is substantial, yielding a figure of $15.35 \%$ at the mean. It shows significant cross sectional variation. For instance, in 1996 tax rates from $14.17 \%$ to $20.37 \%$ are reported. However, since the business tax is deductible in personal and corporate income taxation, the effective tax rate is lower. With $\tau^{N A T}$ denoting the rate of national income taxation, the effective tax rate on capital income $\tau_{i}^{E F F}$ can be computed as

$$
\tau_{i}^{E F F}=\tau_{i}^{L O C}\left(1-\tau^{N A T}\right)+\tau^{N A T} .
$$

It depends on the national income tax rate $\tau^{N A T}$ which varies with the characteristics of the tax payer. ${ }^{4}$ The empirical investigation, however, does not deal with the impact of the overall effective tax rate as such but focuses on the role of interjurisdictional differences. In order to measure tax induced horizontal differences the arbitrage condition (4) is evaluated at different locations and the focus is on the ratio of net and gross returns determined by:

$$
1-\tau_{i}^{E F F}=\left(1-\tau^{N A T}\right)\left(1-\tau_{i}^{L O C}\right) .
$$

As the income tax rate $\tau^{N A T}$ is independent of the location of investment it shows the same effect on the after tax rate of return across locations and the

\footnotetext{
${ }^{4}$ For instance, the effective tax rate on retained earnings of a corporation in 1996 was increased by the business tax by 8.2 percentage points on average, calculated using the corporation tax rate of $48.4 \%$ (including the unification levy (Solidaritaetszuschlag)). The 1996 figure for the private German tax payer with the top rate is quite similar.
} 
Table 2: Descriptive Statistics

\begin{tabular}{cccccccccc}
\hline \multicolumn{1}{c}{ Tax Base per Capita } & \multicolumn{2}{c}{ Exog. Rev. per Capita } & \multicolumn{3}{c}{ Tax Rate } \\
year & mean & min & $\max$ & mean & $\min$ & $\max$ & mean & min & max \\
\hline 1980 & 2.816 & -0.144 & 29.52 & 0.739 & 0.191 & 1.919 & 15.09 & 13.74 & 18.46 \\
1981 & 2.555 & -0.353 & 26.58 & 0.691 & 0.176 & 1.611 & 15.10 & 13.74 & 18.46 \\
1982 & 2.301 & -0.410 & 26.50 & 0.678 & 0.193 & 1.661 & 15.17 & 13.74 & 18.46 \\
1983 & 2.180 & -0.145 & 27.43 & 0.684 & 0.206 & 1.638 & 15.17 & 13.74 & 18.46 \\
1984 & 2.237 & -0.490 & 30.86 & 0.702 & 0.271 & 1.469 & 15.20 & 13.74 & 18.46 \\
1985 & 2.274 & -0.161 & 33.75 & 0.765 & 0.253 & 1.758 & 15.22 & 13.96 & 18.46 \\
1986 & 2.570 & -0.239 & 44.01 & 0.839 & 0.351 & 1.874 & 15.23 & 13.96 & 18.65 \\
1987 & 2.742 & -1.680 & 46.31 & 0.905 & 0.376 & 2.206 & 15.24 & 13.96 & 18.65 \\
1988 & 2.806 & -0.258 & 36.79 & 0.924 & 0.114 & 2.362 & 15.26 & 13.96 & 18.65 \\
1989 & 2.988 & -0.436 & 44.08 & 0.977 & 0.296 & 2.628 & 15.28 & 14.17 & 19.15 \\
1990 & 3.072 & -0.338 & 40.32 & 0.907 & 0.353 & 2.530 & 15.30 & 14.17 & 19.15 \\
1991 & 3.032 & -0.234 & 41.55 & 1.005 & 0.356 & 2.645 & 15.37 & 14.17 & 19.80 \\
1992 & 3.075 & -3.454 & 28.33 & 1.020 & 0.445 & 2.486 & 15.43 & 14.17 & 19.80 \\
1993 & 2.877 & -0.372 & 49.34 & 0.999 & 0.416 & 2.082 & 15.52 & 14.17 & 19.80 \\
1994 & 2.790 & -3.590 & 35.26 & 0.945 & 0.284 & 2.024 & 15.62 & 14.17 & 19.80 \\
1995 & 2.521 & -2.281 & 26.49 & 0.927 & 0.257 & 1.578 & 15.84 & 14.17 & 20.37 \\
1996 & 2.683 & -1.280 & 37.58 & 0.927 & 0.273 & 1.527 & 15.93 & 14.17 & 20.37 \\
& & & & & & & & & \\
av.* & 2.678 & 0.022 & 27.73 & 0.861 & 0.328 & 1.898 & 15.35 & 14.17 & 18.94 \\
\hline
\end{tabular}

Tax base and exogenous revenues in 1,000 DM per capita in prices of 1996. Own computations for 1110 communities in the state of Baden-Wuerttemberg. ${ }^{*}$ statistics for long-term averages 1980-1996. 
first term at the right-hand side drops out of the arbitrage condition. Thus, what matters for location decisions within Germany is the wedge driven by the local tax rate $\tau_{i}^{L O C}$ between returns after income tax and returns after all taxes. In other words, the model suggests that the reduction of the net rate of return relative to the reduction caused by the income tax affects the location decisions. ${ }^{5}$

Whereas the theoretical model has dealt with only two jurisdictions, the empirical investigation requires the operationalization of the concept of opportunity or competing locations. For that purpose it seems helpful to use the notion of neighborhood and to define for each jurisdiction a set of neighbors, whose fiscal decisions might affect the local jurisdiction. Although neighborhood is a rather general concept, and need not necessarily be defined in a geographical sense (cf. Case et al., 1993) the recent empirical literature on local tax competition as cited in the introduction suggests that geographical proximity plays an important role. Following this line of research, the empirical analyses uses a set of spatial weights in order to calculate weighted averages of the fiscal parameters of the jurisdictions in the local neighborhood. As usual in empirical studies with spatial effects the concept used to define the neighborhood is set a-priori and not determined simultaneously with the estimation. However, a concept of neighborhood is employed which has given the best results among a large set of alternatives in a previous attempt to describe the local interdependence of taxing decisions (see appendix C).

\subsection{Estimation approach}

The basic difficulty in estimating the influence of determinants of the business tax base is to ascertain a possibly lagged response in the tax base in the rather fluctuating measure of the tax base available to this study. A full representation of the underlying dynamics seems difficult given a dataset with observations for only 17 years. However, the recent literature on panel data estimation has developed procedures aimed at improving the quality of the empirical representation of dynamic processes. In order to take account of unobserved heterogeneity individual effects should be allowed for, which - in the current context - would pick up the given locational characteristics

\footnotetext{
${ }^{5}$ If cost of mobility were taken into account the income tax rate would not drop out of the arbitrage condition. In this case, the income tax rate constitutes a barrier to mobility as it is after tax earnings which have to exceed mobility costs in order to trigger relocation. However, the relative attractiveness of the locations would still be determined by the local tax rates.
} 
determining the attractiveness as a business location. They also pickup the basic cross-sectional correlation between the jurisdictions (cf., Case, 1991). Whereas the tax base of the business tax fluctuates with the business cycle the tax rates display a rather gradual trend. Therefore, it seems difficult to assume constant slope parameters, a-priori, and, it may be that even the variance of the cross-sectional distribution picked up by the individual effects is not-constant over time.

Given these challenges to specification, it seems appropriate to follow the suggestions by Holtz-Eakin, Newey, and Rosen (1988) which build up an estimator relying on the quasi-differencing procedure of Chamberlain (1983). Within a dynamic panel data context this estimator allows to explicitly test whether parameters including the variance of the individual effects are constant over time. Accordingly, it is assumed that the true representation of the tax base is

$$
\begin{aligned}
b_{i, t}=\alpha_{0, t} & +\sum_{l=1}^{m} \alpha_{1, l, t} b_{i, t-l}+\sum_{l=1}^{m} \alpha_{2, l, t} \bar{\tau}_{i, t-l}+\sum_{l=1}^{m} \alpha_{3, l, t} \tau_{i, t-l} \\
& +\sum_{l=1}^{m} \alpha_{4, l, t} \bar{z}_{i, t-l}+\sum_{l=1}^{m} \alpha_{5, l, t} z_{i, t-l}+\Psi_{t} f_{i}+\epsilon_{i, t}, \quad m \geq 1
\end{aligned}
$$

where $b_{i, t}$ denotes the tax base per capita as observed at location $i$ in period $t . \tau_{i, t}$ and $z_{i, t}$ are the corresponding tax rate and grants per capita, respectively. $f_{i}$ is the unobserved individual effect. Tax rates and revenues denoted with a bar $\left(\bar{\tau}_{i, t}, \bar{z}_{i, t}\right)$ represent averages across the local neighborhood using a spatial weighting scheme (see above). As tax rates are set in advance and grants only react with a time lag to the current revenues simultaneity might be less of problem (see appendix B for a discussion of the determination of the grants). Nevertheless, all explanatory variables on the right hand side are lagged, because the current tax obligation depends on income in the previous year (see appendix $\mathrm{C}$ on the timing of the tax obligation).

Note, that all coefficients are indexed with the time period. Hence, (8) constitutes a system of period specific equations. In order to remove individual effects equation (8) is transformed into quasi-differences, adjusted for the change in the impact of the individual effect $\Psi_{t}$, yielding the estimation equation

$$
b_{i, t}=d_{0, t}+\sum_{l=1}^{m+1} d_{1, l, t} b_{i, t-l}+\sum_{l=1}^{m+1} d_{2, l, t} \bar{\tau}_{i, t-l}+\sum_{l=1}^{m+1} d_{3, l, t} \tau_{i, t-l}
$$




$$
+\sum_{l=1}^{m+1} d_{4, l, t} \bar{z}_{i, t-l}+\sum_{l=1}^{m+1} d_{5, l, t} z_{i, t-l}+u_{i, t},
$$

where the individual parameters are specific combinations of the underlying structural coefficients of equation (8) (for the details see Holtz-Eakin et al., 1988: 1374f).

\subsection{Specification issues}

The available dataset provides 17 consecutive years of observation. Even with immediate adjustment of the tax base two lags $(m=2)$ should be allowed for in equation (8) (see appendix C), since the tax base is calculated from revenue data comprising payments in advance as well as tax rebates (see appendix $\mathrm{C}$ ). To take account of slow adjustment a model is estimated with three lags $(m=3)$ in the structural equation which requires the use of four lags in the differenced estimation procedure. ${ }^{6}$ Even though the right hand side variables can be considered as predetermined with respect to the current tax base (and with respect to the following years' revenues) the first lag is no valid instrument in the quasi-differencing procedure (cf., Holtz-Eakin et al., 1988), and estimation is only possible for 12 time periods. In specifying the set of instruments not all available instruments were employed in order to keep the GMM-estimator's weighting matrix within feasible dimensions. If available, each equation employs one lag more in its specific set of instruments as is required for identification. That is, observations of the periods $\mathrm{t}-2, \ldots \mathrm{t}-\mathrm{m}, \mathrm{t}-(\mathrm{m}+3)$ are used as instruments. The basic estimation thus consists of estimating the 12 period specific equations with 55 overidentifying restrictions. ${ }^{7}$

As depicted in Table 3 the statistic of the test of overidentifying restrictions (denoted with Q) does not suggest to reject the orthogonality of instruments (cf. column 3). Using the basic specification the appropriateness of various parameter restrictions is tested. Following the suggestions of Holtz-Eakin et al. (1989) the first restriction imposed is that the impact of the individual effects is constant across periods $\left(\Psi_{t}=1, t=1, \ldots, 12\right)$. As is displayed by

\footnotetext{
${ }^{6}$ An alternative specification with five lags $(\mathrm{m}=4)$ showed weak convergence indicating numerical problems with the enlarged weighting matrix of the GMM-estimator.

${ }^{7}$ In order to get a reliable estimate of the weighting matrix given the computational restriction to the lag-length first-step estimation is carried out using 3SLS rather than 2SLS taking into account possible error correlation between periods.
} 
Table 3: Model selection

\begin{tabular}{|c|c|c|c|c|c|c|}
\hline $\begin{array}{l}\text { condition } \\
\qquad(1)\end{array}$ & $\begin{array}{l}\text { dof } \\
(2)\end{array}$ & $\begin{array}{c}\text { Q [P-val. }] \\
(3)\end{array}$ & & $\begin{array}{c}\text { additional } \\
\text { restriction } \\
\text { (4) }\end{array}$ & $\begin{array}{l}\text { dof } \\
(5)\end{array}$ & $\begin{array}{c}\mathrm{L}[\mathrm{P}-\mathrm{val} .] \\
(6)\end{array}$ \\
\hline (I) 4 lags $(m=3)$ & 55 & $53.4[.536]$ & (i) & $\begin{array}{l}\text { stationary } \\
\text { individ. effects }\end{array}$ & 45 & $54.1[.167]$ \\
\hline $\begin{array}{l}\text { (II) } 4 \text { lags }(m=3) \\
\text { and stationary } \\
\text { individ. effects }\end{array}$ & 100 & $103.1[.396]$ & $\begin{array}{l}\text { (ii) } \\
\text { (i) } \\
\text { (ii) } \\
\text { (iii) } \\
\text { (iv) }\end{array}$ & $\begin{array}{l}3 \text { lags }(m=2) \\
3 \text { lags }(m=2) \\
\text { no tax effects } \\
\text { no exp. effects } \\
\text { all parameters } \\
\text { stationary, } \\
\left(\text { except } a_{0, t}\right)\end{array}$ & $\begin{array}{l}65 \\
78 \\
78\end{array}$ & $\begin{array}{l}102.9[.002] \\
259.4[.000] \\
123.0[.000] \\
214.4[.000]\end{array}$ \\
\hline
\end{tabular}


the L-Statistic in column (6) this restriction cannot be rejected. ${ }^{8}$ However, the reduction of the lag length to three periods $(m=2)$ is rejected and, thereby, slow adjustment in the true tax base is confirmed. The reduction of the lag length was rejected also when testing conditional on the stationarity of the individual effects. Two further statistics indicate that tax effects and expenditure effects are significant, separately. The usual parameter restriction of equal slopes across equations is also rejected. Therefore, the subsequent analysis employs a model with period specific coefficients, four lags $(\mathrm{m}=3)$, and stationary individual effects.

\subsection{Estimation results}

In order to obtain results on the sign and magnitude of the effect of each variable the results can possibly be best summarized by listing the sum of the coefficients for each variable. For instance, accounting for the time required for adjustment the neighbors' tax rate will have a positive impact on the tax base in the long-run, if

$$
\sum_{l=1}^{3} \alpha_{2, l, t}>0
$$

Given that the impact of the individual effect is stationary the sum of structural coefficients is determined by linear cross-equation combinations of estimated parameters

$$
\sum_{l=1}^{3} \alpha_{2, l, t}=\sum_{l=1}^{3} d_{2, l, t}+\sum_{l=1}^{2} d_{2, l, t-1}+d_{2, l, t-2}>0 .
$$

and the sum of structural coefficients can be inferred by summing the estimated parameters across equations. The sum of structural parameters is, however, identified only in 10 of the 12 estimation periods. Similar expressions can be obtained for the other parameters. ${ }^{9}$

Table 4 displays the results. It shows that the sum of the structural coef-

\footnotetext{
${ }^{8}$ This chi-squared statistic tests for the difference between the restricted and unrestricted sum of squared residuals, cf. Holtz-Eakin et al. (1988), 1380f.

${ }^{9}$ In the case of the coefficients of the lagged tax base the sum of the structural coefficients is

$$
\sum_{l=1}^{3} \alpha_{1, l, t}=\sum_{l=1}^{3} d_{1, l, t}+\sum_{l=1}^{2} d_{1, l, t-1}+d_{1, l, t-2}-3 .
$$


Table 4: Estimation results

dependent variable: tax base

$\begin{array}{ll}\text { tax rate } & \text { exog. revenues tax base } \\ \text { neighb. own neighb. own }\end{array}$

$(\bar{t}) \quad(t) \quad(\bar{z}) \quad(z)$

(b)

\begin{tabular}{|c|c|c|c|c|c|}
\hline 1987 & $\begin{array}{l}2.38 \\
(1.05)\end{array}$ & $\begin{array}{l}-1.75 \\
(0.66)\end{array}$ & $\begin{array}{l}-5.98 \\
(4.21)\end{array}$ & $\begin{array}{l}4.04 \\
(1.28)\end{array}$ & $\begin{array}{l}-.295 \\
(0.10)\end{array}$ \\
\hline 1988 & $\begin{array}{l}2.36 \\
(1.03)\end{array}$ & $\begin{array}{l}-1.74 \\
(0.67)\end{array}$ & $\begin{array}{l}-5.11 \\
(3.91)\end{array}$ & $\begin{array}{l}2.53 \\
(1.04)\end{array}$ & $\begin{array}{l}-.368 \text { *x } \\
(0.08)\end{array}$ \\
\hline 1989 & $\begin{array}{l}2.41 \\
(1.04)\end{array}$ & $\begin{array}{l}-1.67 \\
(0.68)\end{array}$ & $\begin{array}{l}-4.08 \\
(3.85)\end{array}$ & $\begin{array}{c}1.38 \\
(0.99)\end{array}$ & $\begin{array}{l}-.410 \text { *丈 } \\
(0.08)\end{array}$ \\
\hline 1990 & $\begin{array}{l}2.34 \\
(1.05)\end{array}$ & $\begin{array}{l}-1.73^{\star} \\
(0.68)\end{array}$ & $\begin{array}{c}-4.86 \\
(3.55)\end{array}$ & $\begin{array}{l}1.65 \\
(0.99)\end{array}$ & $\begin{array}{l}-.408 \text { *x } \\
(0.07)\end{array}$ \\
\hline 1991 & $\begin{array}{l}2.48 \\
(1.05)\end{array}$ & $\begin{array}{l}-1.78 \\
(0.69)\end{array}$ & $\begin{array}{l}-5.90 \text { * } \\
(3.43)\end{array}$ & $\begin{array}{l}2.03 \text { * } \\
(1.05)\end{array}$ & $\begin{array}{l}-.360 \text { ^夫 } \\
(0.07)\end{array}$ \\
\hline 1992 & $\begin{array}{l}2.50 \\
(1.06)\end{array}$ & $\begin{array}{l}-1.71 \\
(0.71)\end{array}$ & $\begin{array}{c}-5.46 \\
(3.46)\end{array}$ & $\begin{array}{l}1.05 \\
(1.12)\end{array}$ & $\begin{array}{l}-.5666^{\text {*x }}(0.07)\end{array}$ \\
\hline 1993 & $\begin{array}{l}2.21 \\
(1.05)\end{array}$ & $\begin{array}{l}-1.74 \\
(0.74)\end{array}$ & $\begin{array}{l}-6.74 \\
(3.45)\end{array}$ & $\begin{array}{c}0.79 \\
(1.19)\end{array}$ & $\begin{array}{l}-.730 \\
(0.09)\end{array}$ \\
\hline 1994 & $\begin{array}{l}2.08 \text { * } \\
(1.06)\end{array}$ & $\begin{array}{l}-1.75 \\
(0.79)\end{array}$ & $\begin{array}{l}-6.62 \\
(3.37)\end{array}$ & $\begin{array}{c}0.93 \\
(1.50)\end{array}$ & $\begin{array}{l}-.908 \\
(0.09)\end{array}$ \\
\hline 1995 & $\begin{array}{l}1.94 \\
(1.10)\end{array}$ & $\begin{array}{l}-1.61 \\
(0.82)\end{array}$ & $\begin{array}{l}-6.04 \\
(3.77)\end{array}$ & $\begin{array}{l}1.91 \\
(2.12)\end{array}$ & $\begin{array}{l}-.994 \text { ㅊ } \\
(0.11)\end{array}$ \\
\hline 1996 & $\begin{array}{l}3.48 \\
(1.41)\end{array}$ & $\begin{array}{l}-1.79 \star \\
(0.99)\end{array}$ & $\begin{array}{l}-7.33{ }^{\star} \\
(4.29)\end{array}$ & $\begin{array}{l}4.51 \text { * } \\
(2.70)\end{array}$ & $\begin{array}{l}-.830 \text { 太夫 } \\
(0.13)\end{array}$ \\
\hline
\end{tabular}

Sum of coefficients from GMM estimation of the system of period specific equations (9) subject to the restriction of four lags $(\mathrm{m}=3)$ and stationary individual effects. Standard errors in parentheses. The coefficients are marked with one or two stars, depending on whether the significance level is 0.1 or 0.05 respectively. 
ficients generally has the expected sign. ${ }^{10}$ The neighbors' tax rates have a positive impact, which is significant in all years, indicating the presence of fiscal neighborhood externalities. The own tax rate has a negative impact, which is significant in all years. This indicates that the average community is not able to increase its revenues proportionally with the tax rate, and, thus, is facing a "revenue hill" (cf. Inman, 1995, and Haughwout et al., 2000) with a slope of less than unity. The coefficient of the local tax rate is somewhat smaller in absolute value than that of the coefficient of the neighbors' tax rates. The above theoretical derivation of the effects has shown that this is consistent with an impact of public expenditures on the local productivity. But, formal testing using Wald-statistics shows that one can only reject the equality in absolute value for the period 1996. Hence, it can be stated that a joint increase of the tax rate at the local jurisdiction and in the neighborhood has no significant effect on the local tax base.

For the grants the results give a similar picture although the significance is much weaker. An increase in the own revenues tends to have a positive effect, whereas the increase in the neighbors' revenues tends to have a negative influence. This supports the hypothesis that the budget has in fact some positive impact on local productivity. But, again, it was tested whether the coefficients are equal in absolute value and based on a Wald statistic this could not be rejected. This indicates that if there are productivity effects of local public expenditures they are much weaker than the effects of the tax rates.

The last column in Table 4 shows the sum of the coefficients for the lagged tax rates following equation 11 . The significant negative coefficients seem to indicate that there is not a gradual adjustment process of the tax base but rather an overshooting reaction. However, the negative correlation across time in the tax base can be attributed to the fact that the underlying tax revenues do not reflect the current tax obligation. As is shown in appendix $\mathrm{C}$, an overshooting response of the employed measure of the tax base to an innovation in the tax base can be expected from the way the tax is administered.

\footnotetext{
${ }^{10}$ The fact that the sum of coefficients shows only small changes across years it not a contradiction to the result from specification testing that parameters are different across periods. Rather, it indicates that the time pattern of the adjustment varies whereas the total effect stays roughly similar.
} 


\subsection{Quantitative interpretation}

Taking into account the coefficient for the lagged tax base the average point estimate of the long-run effect of an increase in the tax rate is

$$
\frac{\mathrm{d} b_{i}}{\mathrm{~d} \tau_{i}}=\frac{-1.726}{1+0.587}=-1.088
$$

indicating that the tax base is reduced by DM 1,088 per capita ${ }^{11}$ if the tax rate is increased by one percentage point, ceteris paribus. In order to get an impression about the magnitude of this estimate the relative impact is calculated at mean values of the tax rate and the tax base using the statistics of Table 2. This gives an average elasticity of the tax base with respect to an increase in the own tax rate of about ${ }^{12}$

$$
\frac{\mathrm{d} \log b_{i}}{\mathrm{~d} \log \tau_{i}}=-5.86
$$

This is a rather strong effect, since a policy of revenue maximization would imply an elasticity of (minus) unity. As the elasticity shows a higher absolute value this seems to indicate that the tax revenues would rise if the tax rate is reduced, i.e. the average jurisdiction seems to be at the downward sloping part of its revenue hill.

However, this apparent deviation from a revenue oriented policy can be explained by a closer look at the state's fiscal institutions. First, there is vertical revenue sharing with the county, the state, and the federal level. Second, there is also substantial horizontal revenue sharing or "fiscal equalization", which strongly redistributes revenues between the state's communities. Probably, since taking away a part of the tax revenues brings about particularly strong disincentives on the taxing effort of the local jurisdictions, the fiscal transfers are not directly determined by the actual tax revenues but by the taxing capacity of jurisdictions defined by some measure of the tax base. As a consequence, given the tax base a change in revenues due to a change in the local tax rate is fully reflected in the local budget. But, a change in revenues due to a change in the tax base at a given tax rate is only to a limited extent affecting the local budget, since a major part is shifted vertically to the upper fiscal tiers and horizontally to other local communities. Therefore, if an increase of the local tax rate reduces the tax

\footnotetext{
${ }^{11}$ The estimation employs tax base and grants in terms of 1,000 DM per capita.

${ }^{12}$ Evaluated using the mean of the tax base and the tax rate in the periods 1987-1996 and 1986-1995 respectively.
} 
base, the local jurisdiction exerts negative fiscal externalities onto others by reducing transfers paid and increasing the grants received. A similar type of negative fiscal externality is known from the discussion about vertical tax competition (e.g., Wrede, 1997, and Keen, 1998).

As shown in appendix B, the revenue sharing institutions imply to replace the grants variable in the above budget equation (2) by

$$
z_{i}=\bar{z}_{i}-\tau^{R S} b_{i}
$$

where the first term on the right hand side denotes grants received irrespective of the local tax base. The second term captures the role of the local tax base in determining the net volume of grants received. $\tau^{R S}$ can be regarded as an implicit tax of the revenue sharing system (RS). Differentiating the modified revenue equation with respect to the tax rate the following condition is obtained for maximizing the revenues net of transfers

$$
\frac{\mathrm{d} \log b_{i}}{\mathrm{~d} \log \tau_{i}} \stackrel{!}{=}-\left[1-\frac{\tau^{R S}}{\tau_{i}}\right]^{-1} .
$$

Accordingly, if the implicit tax of the system approaches zero $\left(\tau^{R S}=0\right)$, revenue maximization implies an elasticity of the tax base of unity (in absolute value). But if there is significant revenue sharing, maximization of revenues net of transfers goes along with an elasticity of the tax base above unity (in absolute value). If the implicit tax rate would approach the actual tax rate, all effects on the tax base would be shifted onto others and net revenue maximization would be achieved even with an infinite absolute value of the tax base elasticity.

Although the complexity of the revenue sharing system makes it difficult to come up with an general figure, a detailed inspection of its main rules reveals that for a representative jurisdiction the level of the implicit tax rate is in fact at least $80 \%$ of the its tax rate (see appendix B). Similar calculations by the local governments association obtain a figure of $85 \%$ (cf. Kopp, 1994). Therefore, a net-revenue maximizing tax policy of local jurisdictions would be consistent with a tax base elasticity above 5 (in absolute terms). Since the estimated elasticity is not significantly different from that value, we can state that, taking into account the revenue sharing system, the average local jurisdiction is at the top of its net-revenue hill. 


\section{Summary and conclusions}

This paper has presented a test of a central tenet in the recent literature on tax competition, namely, that local jurisdictions taxing a mobile factor cause significant externalities on other jurisdictions. Since recent empirical findings point to a significant interdependence of tax rates among geographic neighbors the analysis has focused on neighborhood externalities. Using a large panel of local jurisdictions the results confirm the existence of fiscal externalities. An increase of the own tax rate significantly lowers the local tax base whereas an increase in the neighbors' tax rates raises the local tax base. The two effects are approximately of the same size in absolute value indicating that a joint increase of the tax rate at the local jurisdiction and in its neighborhood has no effect on the interjurisdictional distribution of the tax base. However, it should be noted that the empirical analysis has removed state wide effects and focused on the change of the distribution of the tax base within the state. Therefore, the results are not suggesting that a joint tax increase in the whole state would not have adverse effects on the tax base. Nevertheless, the symmetry of the tax effects points to rather weak productivity effects of public expenditures which is also confirmed by the weak significance of grants.

The estimated tax base effects of the tax rates are quite strong, indicating an apparently paradoxical situation where a reduction of the local tax rate would lead to an increase of the local tax revenues. However, this can be attributed to the existence of substantial intergovernmental transfers related to revenue sharing: a reduction in the tax base goes along with a reduction in transfer obligations due to vertical revenue sharing as well as with an increase in fiscal "equalization grants" received. A detailed inspection of the revenue sharing rules has revealed that net of transfers the average community is at the top of its revenue hill. Hence, although the empirical analysis supports the existence of fiscal externalities in local tax competition the local jurisdictions do not experience an impact on their perceived marginal cost of raising public funds. In that respect, the revenue sharing institutions serve as a device to internalize fiscal externalities. However, a thorough welfare assessment would have to take into account that local revenue sharing reduces the incentive for local jurisdictions to raise their tax base as they can rely on intergovernmental grants. In addition, the literature on vertical tax competition suggests that in the considered case additional disincentives arise from the vertical dimension of the revenue sharing system. 


\section{A The German business tax}

In the period under investigation German business taxation is a combination of taxes on earnings and capital. The local communities determine the actual tax rates by choosing a multiple or collection rate (Hebesatz) which is applied to basic tax rates of $5 \%$ on earnings and $0.2 \%$ on capital (cf. International Bureau of Fiscal Documentation, 1994: 146). Accordingly, the revenues are described by a function

$$
R_{i}=c_{i}\left[0.05\left(E_{i}-R_{i}\right)+0.002 K_{i}\right],
$$

where the tax base is determined by the business earnings $E_{i}-R_{i}$ (after deduction of the tax payments), the amount of business capital $K_{i}$, and the multiple $c_{i}$. As the definition of taxable business earnings not only includes profits but also a major part of interest payments, the tax on business earnings can be regarded as a capital income tax. The basic tax rates and the definition of taxable earnings and taxable capital in the tax code determine the weights of business earnings in the combined tax base. According to the Business Tax Statistics, in 1995 the weight of earnings is much higher than that of capital as $89.8 \%$ of tax payments belong to the tax on business earnings (cf. German Statistical Yearbook, 1999: 529). As revenues in 1995 where particular low because of the weak performance of the German economy, the weight of business earnings might even be higher in other periods. However, the local revenues derived from the two sources are not reported separately. We, therefore, simplify the analysis and treat the whole business tax as a tax on capital income. For that purpose the local tax rate is approximated by

$$
R_{i} \approx \tau_{i}^{L O C} E_{i}, \quad \text { where } \quad \tau_{i}^{L O C}=\frac{c_{i} 0.056}{1+c_{i} 0.05}
$$

The approximation uses the fact that the average ratio of the taxable base of capital and earnings tax before deduction of taxes is 2.976 (cf. German Statistical Yearbook, ibid.). Replacing business capital in equation (16) and isolating earnings gives the expression. In order to check whether the results are sensitive to variations in the approximation of the local tax rate, estimations have also been carried out without an adjustment for the business capital. The results were almost identical. 


\section{B The implicit tax of the revenue sharing system}

In the considered case, the local jurisdictions have discretion in setting the tax rate but they do not have full autonomy in using the tax revenues collected due to revenue sharing at large scale. ${ }^{13}$ It should be noted, however, that the transfers related to this system are not directly determined by the actual tax revenues but by the taxing capacity of jurisdictions defined by some measure of the tax base. Therefore, additional revenues due to an increase in the tax rate at the given tax base are fully received by the jurisdiction. But, additional revenues due to an increase in the tax base are not. In order to assess the actual net revenue effect of taxing decisions, this appendix shows how the institutional rules can be feed explicitly into the above model. For that purpose, the budget constraint (2) is augmented by transfer obligations $t r_{i}$ and "fiscal equalization" grants $z_{i}^{F E}$.

$$
e_{i}=\tau_{i} b_{i}+z_{i}^{0}-t r_{i}+z_{i}^{F E},
$$

where $z_{i}^{0}$ denotes grants not related with the revenue sharing. For a typical jurisdiction, there are basically three different transfer obligations: obligations due to vertical revenue sharing $\left(\operatorname{tr}_{i}^{V R}\right)$, contributions to the county budget $\left(\operatorname{tr}_{i}^{C C}\right)$, and contributions to the fiscal equalization system $\left(\operatorname{tr}_{i}^{F E}\right)$.

$$
\begin{aligned}
t r_{i} & =t r_{i}^{V R}+t r_{i}^{C C}+t r_{i}^{F E}, \quad \text { where: } \\
t r_{i}^{V R} & =\tau^{V R} b_{i} \quad \text { (vertical revenue sharing), } \\
t r_{i}^{C C} & =\mu^{C C}\left[\left(\tau^{F E}-\tau^{V R}\right) b_{i}+z_{i}^{F E}\right] \quad \text { (county contribution), } \\
t r_{i}^{F E} & =\mu^{F E}\left[\left(\tau^{F E}-\tau^{V R}\right) b_{i}+\lambda z_{i}^{F E}\right] \quad \text { (equalization contribution)(.22) }
\end{aligned}
$$

The transfer obligation due to vertical revenue sharing is simply defined by a standard tax rate on the tax base $\tau^{V R}$ (cf. equation 20). The transfer obligations to the county and into the fiscal equalization system are determined as fractions $\mu^{C C}, \mu^{F E}$ of standardized revenues which include (part of) the equalization grants (cf. equations 21 and 22). The equalization grants are defined as a fraction $(70 \%)$ of the difference between fiscal needs $n_{i}$ and standardized revenues, where the needs are determined mainly by characteristics of the local population.

$$
z_{i}^{F E}=0.7\left[n_{i}-\left(\tau^{F E}-\tau^{V R}\right) b_{i}\right] .
$$

\footnotetext{
${ }^{13}$ There are only very few descriptions of Germany's local government finance available in English. The interested might refer to Norton (1994, 237ff.). A standard reference in German is Junkernheinrich (1991).
} 
Inserting into equation (18) yields the following definition of the revenues after transfers

$$
\begin{aligned}
e_{i} & =\bar{z}_{i}+\tau_{i} b_{i}-\tau^{R S} b_{i} \\
\bar{z}_{i} & =z_{i}^{0}+0.7 n_{i}\left(1-\lambda \mu^{F E}-\mu^{C C}\right) \\
\tau^{R S} & =\tau^{V R}+\left(\tau^{F E}-\tau^{V R}\right)\left(\mu^{F E}+\mu^{C C}+0.7\left(1-\lambda \mu^{F E}-\mu^{C C}\right)\right)
\end{aligned}
$$

Table 5 gives an overview of the parameters determining $\tau^{R S}$ in the time period of the investigation. Following the common praxis in the German literature it reports the multiples instead of the transformed local tax rate in order to facilitate direct comparisons. However, the key parameter in the above analysis, the ratio of the total implicit tax rate of the revenue sharing system to the tax rate $\tau^{R S} / \tau_{i}$ is invariant to the transformation of the tax rate and thus is equal to the ratio of the corresponding multiples $c^{R S} / c_{i}$. The first two columns report contribution rates in percentage to the state's fiscal equalization system (column 1) and the average contribution rate to the local county (column 2). Columns (3) to (5) display key parameters for the definition of local taxing capacity. Columns (3) and (4) report standard multiples for the equalization system and vertical revenue sharing, respectively. The percentage rate in column (5) determines the share of equalization grants which are taken into account in the calculation of the county contributions. The last three columns display the consequences of the system. It turns out that on average the ratio between the implicit multiple of the revenue sharing system $c^{R S}$ to the median tax rate is about $80 \%$. However, as pointed out by Kopp (1994) there are additional tax base dependent features of the revenue sharing system like the investment grants (Investitionspauschale) which are not taken into account. In addition approximately a third of all jurisdictions receives additional grants in order to reach a guaranteed minimum budget per capita despite their low taxing capacity. This suggests that the average contribution will be even higher.

\section{Sources and definitions of data}

Communities: The dataset consists of the 1111 communities (Gemeinden) of the state of Baden-Wuerttemberg. In the German system of fiscal federalism the communities build the lowest of the fiscal tiers. The 1111 communities form 44 districts, i.e 35 counties (Kreise) and 9 independent cities (Kreisfreie Staedte). The community of Blaubeuren 
Table 5: Parameters of revenue sharing system

\begin{tabular}{l|cccccc|cc}
\hline Jahr & $\mu^{F E}$ & $\mu^{C C}$ & $c^{F E}$ & $c^{V R}$ & $\lambda$ & $\mathrm{m}\left(c_{i}\right)$ & $c^{R S}$ & $\frac{c^{R S}}{\mathrm{~m}\left(c_{i}\right)} \equiv \frac{\tau^{R S}}{\mathrm{~m}\left(\tau_{i}\right)}$ \\
& & & & & & & & $(8)$ \\
\hline 1980 & 16.00 & 19.18 & 300 & 80 & 100 & 310 & 257.22 & 0.83 \\
1981 & 17.00 & 19.18 & 300 & 80 & 100 & 310 & 257.88 & 0.83 \\
1982 & 17.00 & 19.18 & 290 & 80 & 100 & 310 & 249.79 & 0.81 \\
1983 & 17.00 & 19.18 & 290 & 58 & 100 & 310 & 245.58 & 0.79 \\
1984 & 17.00 & 19.18 & 290 & 52 & 100 & 310 & 244.43 & 0.79 \\
1985 & 17.91 & 19.18 & 290 & 52 & 100 & 310 & 245.08 & 0.79 \\
1986 & 17.75 & 19.30 & 290 & 52 & 75 & 315 & 252.45 & 0.80 \\
1987 & 17.75 & 19.39 & 290 & 52 & 75 & 315 & 252.51 & 0.80 \\
1988 & 17.75 & 19.59 & 290 & 52 & 75 & 315 & 252.65 & 0.80 \\
1989 & 20.10 & 19.71 & 290 & 52 & 75 & 315 & 255.40 & 0.81 \\
1990 & 20.25 & 19.83 & 290 & 52 & 75 & 320 & 255.65 & 0.80 \\
1991 & 19.60 & 19.81 & 290 & 54 & 100 & 320 & 247.10 & 0.77 \\
1992 & 19.60 & 19.60 & 290 & 57 & 100 & 320 & 247.50 & 0.77 \\
1993 & 20.00 & 22.45 & 290 & 39 & 100 & 320 & 246.66 & 0.77 \\
1994 & 20.00 & 24.44 & 290 & 56 & 100 & 320 & 251.00 & 0.78 \\
1995 & 20.00 & 25.77 & 290 & 79 & 100 & 330 & 255.67 & 0.77 \\
1996 & 20.00 &. & 290 & 78 & 100 & 330 &. &. \\
\hline av. & \multicolumn{10}{|c}{} & \\
\hline
\end{tabular}

Source: columns (1), (3), (4), and (5) are taken from Trump (2000). Column (2) reports the average county contribution taken from various publications of the association of communities (Gemeindetag), the value of 1996 was not available at the time this paper was finished. Column (6) reports the statewide median of the multiple. Columns (7) and (8) own calculations, see text. 
(id: 425020) is removed from the dataset as it reports a very high negative tax revenue in 1996 (-25.6 Million DM) resulting from repayments to a large local employer. Whereas an excess of repayments is also observed at other observations the size of this case is rather exceptional.

Tax base: The tax base is calculated from the total revenues of the Business Tax (Gewerbesteueraufkommen, brutto) as reported in the annual budgetary statistics (Jahresrechnungsstatistik) provided by the state's statistical office (Statistisches Landesamt Baden-Wuerttemberg). It is obtained by dividing tax revenues by the tax rate as defined in equation (17). The obtained measure of the tax base is employed in terms of 1,000 DM per capita in constant prices of 1996.

As the tax payments are not strictly related to the tax base in a certain period the measure of the tax base fluctuates strongly around the true tax base. To see this, consider the following approximation, where the tax revenues in year $t$ are made up by payments in advance as well as repayments for the previous period.

$$
R_{i, t}=\tau_{i, t} b_{i, t-1} \quad-\quad \tau_{i, t-1}\left[b_{i, t-2}-b_{i, t-1}\right] .
$$

The first term on the right hand side depicts the current payments in advance according to the tax base in the previous period, the second term displays net repayments. Dividing by the tax rate one obtains a measure of the tax base

$$
\tilde{b}_{i, t-1}=b_{i, t-1}-\frac{\tau_{i, t-1}}{\tau_{i, t}}\left[b_{i, t-2}-b_{i, t-1}\right] .
$$

Taking differences across time yields

$$
\mathrm{d} \tilde{b}_{i, t}=\mathrm{d} b_{i, t}\left(1+\frac{\tau_{i, t}}{\tau_{i, t+1}}\right)-\mathrm{d} b_{i, t-1}\left(\frac{\tau_{i, t-1}}{\tau_{i, t}}\right) .
$$

It follows that a shock in the tax base $\mathrm{d} b_{i, t}$ has a more than proportional effect on the measured tax base $\mathrm{d} \tilde{b}_{i, t}$. In fact, the reported change is twice as large as the true innovation if the tax rate is unchanged. The reason is that an increase in the tax base leads to a reduction of repayments as well as to an increase in advance payments. In the following period, then, it has negative effect by reducing the repayments. As a consequence, one should expect an overshooting reaction and negative autocorrelation in the calculated tax base 
data. However, the effect might be less strong as jurisdictions have some possibility to adjust the payments in advance in certain circumstances, but the quantitative significance cannot be ascertained from the published data.

Local multiples of the local business tax (Gewerbesteuer) for the years (Rechnungsjahre) 1980-1996 are obtained from the state's statistical office.

Grants refers to the sum of "fiscal equalization" grants (Schluesselzuweisungen) and the community's share of income tax revenues (Gemeindeanteil an der Einkommensteuer) reported in the annual budgetary statistics. Matching grants are not included. Employed in terms of 1,000 DM per capita in constant prices of 1996, source: SDRB. Note that income tax revenues are shared with the federal and the state level with common tax rates, nationally.

Price index used is the national producers price index (Erzeugerpreisindex) for West Germany (source: Council of Economic Experts, "Sachverstaendigenrat").

Annual population refers to the first of January, census data, official projections using resident registration information, obtained from the state's statistical office.

Spatial weighting matrix: Euclidian distances are computed from a digital map of the geographical position of the administrative center of each community. The employed matrix defines local neighbors as communities located within a distance of 30 kilometers $(\mathrm{km})$. Each neighboring jurisdiction is weighted according to the inverse of its relative distance. In an attempt to estimate the reaction function of local jurisdictions by means of spatial maximum likelihood techniques (cf., Anselin, 1988), the chosen weighting matrix has shown the best fit (likelihood) in a grid search procedure among several alternatives including larger ranges and different weights (cf. Buettner, 2000). The complete matrix has a dimension of 1111 , shows an average weight of .0236, contains 47028 nonzero links and an average of 42.3 links. The two most connected communities show 83 links, the least connected community display 5 links. From the complete matrix the row referring to the skipped observation (see above) is removed. 


\section{References}

Anselin, L., 1988, Spatial econometrics: methods and models. Dordrecht et al.: Kluwer.

Besley, T. and A. CASE. 1995. Incumbent behavior: vote-seeking, tax-setting, and yardstick competition. American Economic Review 85, 25-45.

Brett, C. and J. Pinske. 1997. Those taxes are all over the map! A test for spatial independence of municipal tax rates in British Columbia. International Regional Science Review 20, 131-151.

Brett, C. and J. Pinske. 2000. The determinants of municipial tax rates in British Columbia. Canadian Journal of Economics 33, 695-714.

Brueckner, J. K. and L. A. SAAvedra. 2000. Do local governments engage in strategic property-tax competition? Paper presented at the Econometric Society World Congress 2000.

Buettner, T. 2001. Local business taxation and competition for capital: the choice of the tax rate. Regional Science and Urban Economics, forthcoming.

Buettner, T. 2000. Steuerwettbewerb im Foederalstaat: Eine empirische Analyse der kommunalen Hebesatzpolitik. In: Buettner, T (ed.). Finanzverfassung und Foederalismus in Deutschland und Europa. Baden-Baden: Nomos, 61-87.

Case, A. C. 1991. Spatial patterns in household demand, Econometrica 59, 4, 953-965.

Case, A. C., H. S. Rosen, and J. R. Hines. 1993. Budget spillovers and fiscal policy interdependence: Evidence from the states, Journal of Public Economics 52, 285307.

Chamberlain, G. 1983. Panel data. In: Griliches, Z. and M. Intriligator (eds.). Handbook of econometrics. Amsterdam: North Holland, Chapter 22.

Haughwout, A, Inman, R., Craig, S., and T. Luce. 2000. Local revenues hills: a general equilibrium specification with evidence from four US Cities. NBER Working Paper 7603.

Henderson, J. V. 1985. Economic theory and the cities. San Diego: Academic Press.

Holtz-Eakin, D., Newey, W. and H. S. Rosen. 1988. Estimating vector autoregressions with panel data. Econometrica 56, 1371-1395.

Holtz-Eakin, D., Newey, W. and H. S. Rosen. 1989. The revenues-expenditures nexus: evidence from local government data. International Economic Review 56, $415-429$.

Inman, R. P. 1995. How to have a fiscal crisis : lessons from Philadelphia. American Economic Review, 85, 378-383.

International Bureau of Fiscal Documentation (ed.). 1994. European tax handbook, 5th. edition. Amsterdam.

Junkernheinrich, M., 1991, Gemeindefinanzen. Theoretische und methodische Grundlagen ihrer Analyse, Berlin: Analytica. 
KeEn, M. J. 1998. Vertical tax externalities in the theory of fiscal federalism. Staff papers / International Monetary Fund 45, 454-485.

Kopp, K. 1994. Was bleibt von 100 DM Gewerbesteuer in der Gemeindekasse? Die Gemeinde - Komunalzeitschrift des Gemeindetags Baden-Wuerttemberg, 94, 1, 1113.

LADD, H. F. 1992. Mimicking of local tax burdens among neighboring counties. Public Finance Quarterly 20, 450-467.

Matsumoto, M. 1998. A note on tax competition and public input provision. Regional Science and Urban Economics 28, 465-473.

Norton, A. 1994. International handbook of local and regional government. Cheltenham and Lyme: Edward Elgar.

OAtes, W. E. 1999. An essay on fiscal federalism. Journal of Economic Literature 37, $1120-1149$.

Richter, W. F. 1994. The efficient allocation of local public factors in Tiebout's tradition. Regional Science and Urban Economics 24, 323-240.

Trumpp, E. (ed.), 1999. Praxis der Gemeindeverwaltung. CD-ROM-Ausgabe Baden Wuerttemberg, Walluf, Germany.

Wildasin, D. E. 1989. Interjurisdictional capital mobility: fiscal externality and a corrective subsidy. Journal of Urban Economics 25, 193-212.

Wilson, J. D. 1999. Theories of tax competition. National tax journal 52, 269-304.

Wrede, M. 1997. Vertical and horizontal tax competition: will uncoordinated Leviathans end up on the wrong side of the Laffer curve? Finanzarchiv, N.F. 53, 461-479. 